\title{
Charism and Challenge - Old Catholic Ecumenism and the Appeal to the Early Church
}

\author{
Peter-Ben SMit ${ }^{*}$
}

This paper explores the role of the appeal to the early Church in Old Catholic theology, describing how this appeal has been challenged and further developed through ecumenical dialogue in particular. Noting the various problems involved in this appeal and the manner in which they have been discussed within the Old Catholic (ecumenical) theological discourse, the paper highlights the process of discernment within the Union of Utrecht of Old Catholic Churches, and from that in particular the consultation with the Ecumenical Patriarchate on the subject, and analyses the role of the appeal to the early church in this setting. Notably, the hermeneutically reflected appeal to the early church paved the way for a theologically responsible manner of opening the apostolic ministry to women as well as men.

Keywords: Early church; Old Catholicism; ecumenism; Orthodoxy; hermeneutics; synodality; conciliarity; women's ordination; ministry.

\section{Introduction}

The appeal to the early Church in ecumenical theology invites considering the Old Catholic tradition, given that it has combined, in all of its formal expressions, precisely these two commitments: (1) a commitment to the early church as a means of shaping (2) an ecumenical commitment. ${ }^{1}$ For instance, the 'charter' of the central international body of the communion of Old Catholic Churches, the so-called 'Declaration of Utrecht' of the International Bishops' Conference of the Old Catholic Churches of the Union of Utrecht, ${ }^{2}$ stated in 1889 in its paragraphs 1 and 7 :

\footnotetext{
* Peter-Ben Smit, Professor (ao.) of Systematic and Ecumenical Theology, University of Bern; Professor of Contextual Biblical Interpretation, Vrije Universiteit (Amsterdam); Professor (by special appointment) of Ancient Catholic Church Structures (Utrecht University); research associate in the Faculty of Theology, University of Pretoria. Address: Berchtoldstrasse 15-4, 3012 Bern, Switzerland, e-mail: Peter-ben.smit@theol.unibe.ch.

This paper is based on and partially reuses materials that also appeared in: Old Catholic and Philippine Independent Ecclesiologies in History. The Catholic Church in Every Place, Leiden 2011, and idem, Old Catholic Theology, Leiden 2019 (forthcoming). References to secondary literature have been kept to a minimum, with emphasis on primary sources in the latter part of the essay. ${ }^{1}$ See in general: Urs von Arx, "Der kirchliche und ökumenische Auftrag der Altkatholischen Kirchen der Utrechter Union: Wie weiter in die Zukunft?”, in: Internationale Kirchliche Zeitschrift 98 (2008), p. 5-49.

2 On its inception, see: e.g., Dick Schoon, "The Union of Utrecht among the Christian World Communities: A Comparative Perspective”, in: Internationale Kirchliche Zeitschrift
} 
(1) We adhere to the principle of the ancient Church laid down by St Vincent of Lérins in these terms: 'Id teneamus, quod ubique, quod semper, quod ab omnibus creditum est; hoc est etenim vere proprieque catholicum'. Therefore we abide by the faith of the ancient Church as it is formulated in the ecumenical symbols and in the universally accepted dogmatic decisions of the ecumenical synods held in the undivided Church of the first millennium.

(7) We hope that the theologians, while maintaining the faith of the undivided Church, will succeed in their efforts to establish an agreement on the differences that have arisen since the divisions of the Church. We urge the priests under our jurisdiction in the first place to stress, both by preaching and by religious instruction, the essential Christian truths professed in common by all the divided confessions, carefully to avoid, in discussing still existing differences, any violation of truth or charity, and, in word and deed, to set an example to the members of our parishes of how to act towards people of a different belief in a way that is in accordance with the spirit of Jesus Christ, who is the Saviour of us all. ${ }^{3}$

More than a century later, this commitment was reiterated in the preamble of the newly revised statute of the same body, reiterating the contents of the 1889 declaration, before proceeding to state the ecclesiology of the Old Catholic Churches:

2. In the "Declaration of Utrecht", fundamental for Old Catholic doctrine, the communion of the Union of Utrecht which came into existence in the context of the First Vatican Council confesses the Catholic faith as expressed in the Church in the east and west by the seven Ecumenical Councils. It approves of the historic precedence of the Bishop of Rome as primus inter pares, but rejects the papal dogmas of the said council and a number of other papal pronouncements as far as they are at variance with the doctrine of the Ancient Church. It affirms its faith in the essence and mystery of the Eucharist. Furthermore the Union of Utrecht shows its awareness of its obligation to do everything that will help to overcome the divisions in the Church, and, based on the faith of the undivided Church, to seek and declare unity and communion with other Churches. ${ }^{4}$

105 (2015), p. 91-103; Wietse van der Velde, “The Declaration of Utrecht”, in: Internationale Kirchliche Zeitschrift 104 (2014), p. 64-67.

3 Reprinted (in translation) in: Urs von Arx and Maja Weyermann (eds.), Statut der Internationalen Altkatholischen Bischofskonferenz (IBK). Offizielle Ausgabe in fünf Sprachen, Bern 2001, ad loc.

4 See: U. von Arx, M. Weyermann (eds.), Statut. 
Yet, the appeal to the faith and order of the early Church is both as programmatic for 'Old Catholicism' as it is potentially problematic, certainly when Old Catholic churches are seen by ecumenical partners to introduce 'novelties', such as the ordination of women to the threefold apostolic ministry. Therefore, the question addressed by this paper is: how does the appeal to the early Church function in Old Catholic theology, with particular attention to its ecumenical commitment and accountability. In order to do so, first a general outline of the understanding of the appeal to the early Church in Old Catholic Church will be given, upon which a particular case is considered: the appeal to the early church in the context of the Old Catholic discernment of the ordination of woman to the apostolic ministry, a theological journey that was ecumenical in nature as well.

\section{Charism and Challenge: The Early Church in Old Catholic Theology}

As was just noted, the appeal to the early Church is both a characteristic, a charism if you like, of Old Catholic theology, as well as a challenge. The latter has to do with the fact that it may be regarded as (1) being indebted to a(n all too) romantic view of the early church, (2) an epistemology that privileges the 'original' in a questionable manner and is subject to epistemological positivism, (3) a historical untenable view of the unity of the early church, and (4) using an entity with unclear boundaries (what are the temporal, institutional and social boundaries of the early church?) and therefore an unclear content. ${ }^{5}$ Yet, this does not hinder Old Catholic theologians from

\footnotetext{
5 For characteristic points of criticism, in this case by Old Catholic authors, see: Kurt Stalder, "Theologische Wissenschaft", in: Internationale Kirchliche Zeitschrift 64 (1974), p. 194220; Matthias Ring, "Ad pristinam normam patrum: Anmerkungen zum alt-katholischen Reformparadigma”, in: Angela Berlis, Klaus-Dieter Gerth (eds.), Christus Spes: Liturgie und Glaube im ökumenischen Kontext, Frankfurt, Peter Lang 1994, p. 255-264. Of course, an internal Old Catholic debate concerning these various matters exists. For instance, it is argued that one of the advantages of the appeal to the early Church in terms of its faith and order is precisely that it refers back to a lived reality and an organic whole, not only a set of theological principles or a particular set of books, such as the Bible and therefore offers an encompassing point of theological departure. See with this emphasis: U. von Arx, "Identity, Plurality, Unity - What's the Right Blend? Some Reflections from an Old Catholic Perspective", in: Jeremy Morris, Nicholas Sagovsky (eds.), The Unity We Have and the Unity We Seek: Ecumenical Prospects for the Third Millennium, London, T\&T Clark 2003, p. 3-26, here p. 4. Also, considering such queries with an eye to "tradition" as the ongoing transmission of the faith, such historical unclarities are even necessary, given that they offer opportunities for the ongoing discovery of new, forgotten or misrepresented aspects of the Church's tradition with an eye to its communication in new contexts. Somewhat counterintuitively therefore, precisely the apparently problematic aspects of an appeal to the early church, in fact make the faith and order of the early church much more conveniently accessible and the connection with the life of the world today is facilitated by it, given that they further a hermeneutical approach to theological tradition. See the argument in: Peter-Ben Smit, Traditie als Missie.
} 
continuing to make appeals to the early church, the point of which is often summed up with Vincentius of Lerinum's famous dictum: "id teneamus quod ubique, quod semper, quod ab omnibus creditum est" (Vincentius Lerinum, Commonitorium II.3). ${ }^{6}$ It has been adopted by the Old Catholic Churches as a quasi-official theological motto (cf. the first paragraph of the 1889 Declaration of Utrecht and the cover of the main Old Catholic theological outlet, the Internationale Kirchliche Zeitschrift). ${ }^{7}$

A motto it may be, but, like the appeal to the earlier church, it is one that is in need of interpretation. Such interpretation has developed in the history of the Union of Utrecht and its theology itself. In it, the appeal to the early Church - and with that to the Vincentian rule - can be seen to have four key functions. ${ }^{8}$ The appeal functions in relation to: (1) the protest against a specific shape of the Church, i.e. as it was the result of the ultramontanization of the church during the $19^{\text {th }}$ century; (2) the formulation of an Old Catholic "creed"; (3) the development of a basis for ecumenical relations; (4) the starting point for ecclesial renewal. Not coincidentally, these are also the four main ingredients of the Declaration of Utrecht of 1889. The four are mutually interrelated and depend on each other, yet, it is helpful to distinguish them.

(1) In the context of resistance against the ultramontanization of the church, the appeal to the early Church during the $19^{\text {th }}$ century (and in the

125 Jaar Unie van Utrecht-1275 jaar in de voetsporen van St. Willibrord, Amersfoort, Publicatieserie Oud-Katholiek Seminarie 2015.

6 The dictum is an abbreviated form of the following text: "In ipsa item catholica ecclesia magnopere curandum est, ut id teneamus, quod ubique, quod semper, quod ab omnibus creditum est. Hoc est etenim vere proprieque catholicum; quod ipsa vis nominis ratioque declarat, quae omnia fere universaliter comprehendit." - For an edition, see: e.g., Martien F.G. Parmentier, Vincentius van Lerinum, de beide Commonitoria, Amersfoort, Stichting Centraal Oud-Katholiek Boekhuis 1989. For interpretations emphasizing the "material" and "formal" aspects of the Vincentian rule, see: Christian Oeyen, "Die alte Kirche als Norm nach Döllinger und seiner Schule", in: Internationale Kirchliche Zeitschrift 86 (1996), p. 25-44, and Jan Visser, "Die Alte Kirche als hermeneutisches Prinzip", in: Internationale Kirchliche Zeitschrift 86 (1996), p. 45-64; idem, "Vincentius van Lerinum en zijn Id teneamus. Over een oud-katholieke lijfspreuk", in: Kees van der Kooi et al. (eds.), Vele gaven, één Geest. Meedenken met Martien Parmentier op het gebied van oecumenica, patristiek en theologie van de charismatische vernieuwing, Gorinchem, Ekklesia 2012, p. 121-129.

7 Although the subsequent considerations will aim at a systematization of the appeal to the early Church with a focus on the emergence of a joint Old Catholic tradition post-1870, it is good to stress here that such an appeal is characteristic of both traditions of "Old Catholicism", given that the "augustinianist" tradition also aimed at a return to the patristic sources. See, e.g.: Mattijs Ploeger, Celebrating Church. Ecumenical Contributions to a Liturgical Ecclesiology, Tilburg-Groningen, Instituut voor Liturgiewetenschap, Liturgisch Instituut 2008, p. 167-170.

8 The following is indebted to discussions with Dr. Adrian Suter, Schönenwerd/Bern on the subject of his Habilitationsprojekt that is dedicated to "Berufung auf die Alte Kirche als Kriterium für Theologie heute”. 
case of the Dutch Church also earlier) ${ }^{9}$ clearly had the function of providing the rationale for the "Old" Catholic protest: the theological and canonical renewal that was taking place was seen to be in contradiction to the faith and order of the early Church and it certainly had not been believed everywhere, always and by all. Vincentius' rule functioned as a way to especially exclude Pastor Aeternus (1870; dogmatization of papal infallibility and papal universal jurisdiction) from the spectrum of legitimate Catholic teaching and to relegate what was expressed in Ineffabilis Deus (1854; Immaculate Conception of Mary) to the realm of possible theological opinion, while excluding it from the realm of dogma. When applying the terminology of material and formal principles of theology: the ultramontanizing dogmatic definitions went against the material principle, i.e. the dogmatic tradition of the early Church. ${ }^{10}$ Yet, this was by no means the only aspect of the protest. It was also argued that the changes went against an episcopal-synodal and conciliar way of existing as a community of reconciliation and engaging in discernment of the truth as such, ${ }^{11}$ as the Dutch bishops had already protested against the dogmatization of the immaculate conception of the Blessed Virgin by pope Pius IX without a General Council in $1854 .{ }^{12}$ In other words: it was argued that the new developments were not "just" at odds with the ancient faith and order as it had existed in the early Church, but in fact contradicted the manner of discerning the truth of the early Church as well, which made things even more serious and the protest all the more urgent. With that, more than just the "validity" of a particular innovation was at stake, but the extent to which the Church could indeed be the (social) space in which salvation could be experienced, i.e. by existing in such a manner that the life of the ecclesial communion could indeed be a conduit for facilitating an encounter with God in Christ through the Spirit, which is at the heart of what it means to be a Catholic Church. ${ }^{13}$ In all of

9 On this church and its history, see: D. Schoon, Van bisschoppelijke Cleresie tot Oud-Katholieke Kerk. Bijdrage tot de geschiedenis van het katholicisme in Nederland in de 19de eeuw, Nijmegen, Valkhof Pers 2004.

10 See: C. Oeyen, "Die alte Kirche".

11 See on this: e.g., Jan Visser, Het ideaal van de ecclesia primitiva, Amersfoort, Centraal Oud-Katholiek Boekhuis 1980; idem, "Kirche", and idem, "Vincentius"; see also Andreas Krebs, ““... den blühendsten Zustand der Kirche wieder herbeizuführen'. Papstkritik und Alte Kirche bei Joseph Hubert Reinkens", in: Internationale Kirchliche Zeitschrift 101 (2011), p. 101-115.

12 See: D. Schoon, Van bisschoppelijke Cleresie, p. 245-253.

13 See the considerations in: Kurt Stalder, Die Wirklichkeit Christi erfahren. Ekklesiologische Untersuchungen und ihre Bedeutung für die Existenz von Kirche heute, Zürich, Benziger 1984; idem, Sprache und Erkenntnis der Wirklichkeit Gottes. Texte zu einigen wissenschaftstheoretischen und systematischen Voraussetzungen für die exegetische und homiletische Arbeit (ed. U. von Arx), 
these ways, this protest based on the faith and order of the early Church still stands in contemporary Old Catholic theology, given that its formal view of the legitimacy of these doctrinal developments has not changed. ${ }^{14}$

(2) The second function of the appeal to the early Church was to furnish the Old Catholic Churches with a viable point of doctrinal orientation. In fact, the protest against the ultramontanization of the Church that was mentioned first - because it was historically the most prominent around the First Vatican Council - is a corollary of a way of developing the Catholic tradition on the basis of the (academically accessed) faith and order of the early Church, not vice versa. Yet, the First Vatican Council made the development of such catholic theology in continuity with the faith and order of the early Church all the more urgent. The appeal to the early Church, certainly in a cultural atmosphere that was both academically and romantically inclined to favor origins as the place where truth might be found, provided a theologically, academically, ecclesially and socially viable point of orientation for the faith and order of the Old Catholic Churches. It has remained this ever since, again with both emphasis on the content of the faith and order of the early Church and with emphasis on the (communal) hermeneutics of the early Church. ${ }^{15} \mathrm{It}$ also meant that the Old Catholics could in good faith remain Catholics and were not forced to go for the "logical" alternative for Roman Catholicism, that is Protestantism. In the course of the $20^{\text {th }}$ century ongoing reflection on the appeal to the early Church and its constructive significance led to the following theological consensus of the 1995 International Old Catholic Theologians' Conference:

Die Internationale Altkatholische Theologenkonferenz ist zu der Feststellung gekommen, dass die Berufung auf die Alte Kirche sich nicht allein auf Glaubensinhalte bezieht, sondern auch auf die Art und Weise, wie man in Fragen des kirchlichen Lebens zu einer Übereinstimmung kommt. Dieser Prozess zur Bewahrung kirchlicher Gemeinschaft war gekennzeichnet von synodalen und konziliaren Beratungen. Er war in der Alten Kirche eingebettet in Einheit und Vielfalt. Diese beiden Prinzipien der «Synodalität»

Freiburg, Universitätsverlag 2000; on this qualitative view of catholicity, see: U. von Arx, "Was macht die Kirche katholisch? Perspektiven einer christkatholischen Antwort", in: Wolfgang W. Müller (ed), Katholizität - Eine ökumenische Chance, Zürich, TVZ 2006, p. 147-186. 14 See: U. von Arx, "Ein «Petrusamt» in der Communio der Kirchen. Erwägungen aus altkatholischer Perspektive”, in: Internationale Kirchliche Zeitschrift 93 (2003) p. 1-42; see also: Adrian Suter, "«Ce qui a été cru partout, toujours et par tous»-la catholicité selon la théologie catholique-chrétienne”, in: François-Xavier Amherdt (ed.), Vers une catholicité cecuménique?, Freiburg, Universitaires De Fribourg Eds 2013, p. 61-70.

15 See: J. Visser, "Kirche". 
und der «Einheit in der Vielfalt» stützen und ergänzen sich gegenseitig. ${ }^{16}$

What this appeal meant positively, rather than just 'negatively' (i.e., as a foundation for rejection illicit innovations) becomes the clearest when focusing on ecclesial reunification and renewal, hence, now its ecumenical function will be discussed.

(3) The third function of the appeal to the early Church was an ecumenical one. ${ }^{17}$ This function is a direct consequence of the orientation towards the early Church and the realization that, in the light of the ultramontanization of the Church as the outcome of a longer tendency in Western Catholicism, the Western (Roman) Catholic tradition could no longer be regarded as the only authentic continuation of the Christian tradition and that the faith and order of the early Church ought to be the norm for authentic Catholicity. When establishing this, church unity, in the sense of recognizing each other's Catholicity, must also have the faith and order of the early Church as its basis. On this basis, it was hoped that confessionalism (in the West and even longer-standing schisms, such as the one between Eastern and Western Christianity), could be overcome. With regard to ecumenical rapprochement, a similar interplay between content of the faith and order of the early Church and its (re)discovery in the modern world can be seen as in the case of both protest and the development of a way of doing Catholic theology in continuation with the faith and order of the early Church: it is about both form and content, about how faith is discerned and about what it has as its content. In other words: only when churches can together, i.e. in a conciliar manner, discern the faith and order of the early Church and its identical presence in the lives of these churches in such a way that this can also be received (episcopally-synodally) by the churches involved, then ecclesial communion has been established. As will be discussed below, the Old Catholic approach to ecumenism avant la lettre would provide a good match with the later Faith and Order Movement, as it issued out of the 1910 World Missionary Conference (Edinburgh), in dialogue with which much later Old Catholic theology has been developed. In the early years of the Altkatholische Bewegung, this approach to ecumenism led to a principled focus on the Church of Utrecht, the Orthodox Churches

${ }^{16}$ International Old Catholic Theologians' Conference, "[Resolution]", in : Internationale Kirchliche Zeitschrift 86 (1996), p. 15.

${ }_{17}$ See for an outline: U. von Arx, "Der kirchliche und ökumenische Auftrag "; more extensively: Harald Rein, Kirchengemeinschaft: Die anglikanisch-altkatholisch-orthodoxen Beziehungen von 1870 bis 1990 und ihre ökumenische Relevanz 1-2, Bern, Peter Lang 19931994; see also: P. B. Smit, Ecclesiologies, and idem, Tradition in Dialogue. The Concept of Tradition in International Anglican Bilateral Dialogues, Amsterdam, Vu University Press 2012. 
and the Anglican Churches, as churches that were likely to have continued the faith and order of the early Church in a manner similar to the Old Catholics. Following the formalization of relations with the Church of Utrecht (episcopal consecrations in the 1870s and the establishment of the Union of Utrecht in 1889), a trilateral ecumenical project was pursued with the Orthodox and Anglican Churches in particular.

(4) A fourth and final function of the appeal to the faith and order of the early Church has to do with the theological and organizational renewal (and with that: spiritual renewal) of the Old Catholic Churches. Here, again form and content cohere: the faith and order of the early Church can only be received and confessed when justice is done to the manner of discerning the truth of the early Church. ${ }^{18}$ In line with this, a strengthening of synodal structures was one of the first, if not the first, step taken to renew the life of the Church on the basis of the faith and order of the early Church (in the churches emerging out of the Altkatholische Bewegung this took the form of modern synods in the $19^{\text {th }}$ century, in the Dutch Church, synodal awareness existed even without a "modern" synod, given its ecclesiological tradition, cf. above). Subsequent renewal in the life of the churches, whether it pertained to the liturgical life (e.g., the introduction of the vernacular, the revision of liturgical rites in general, etc. $)^{19}$, church order (e.g., the abolition of compulsory clerical celibacy, the ordination of both women and men to the apostolic ministry, etc.), or matters at the interface of ethics and theological anthropology, have usually been discerned both within the communion of a local church and within the communion of communions of churches that the Union of Utrecht is, ideally leading either to a common mind or to the insight that different practices need not be church dividing. Tensions and differences are inherent to this process, yet also serve the purpose of furthering and deepening the conversation, rather than being obstacles in the way of centrally decreed ordinances. This is the nature of synodality and conciliarity as theological and therefore spiritual processes: communion and dialogue is predicated on difference. ${ }^{20}$ In fact, it precisely facilitates the process to which Old Catholic theologians also referred when they argued that the faith of the early Church needs to be "rethought" for today in order to remain faithful to it and when they underlined that salvation should also

\footnotetext{
18 As emphasized by, e.g., U. von Arx, "Was macht die Kirche"; Adrian Suter "Altkatholische Kirchen”, in: Johannes Oeldemann (ed.), Konfessionskunde Leipzig-Paderborn, Evangelische Verlagsanstalt 2016, p. 247-274; M. Ploeger, Celebrating Church.

19 See: U. von Arx, "Altkatholische Liturgie im 19. und 20. Jahrhundert", in: Jürgen Bärsch et al. (eds.), Geschichte der Liturgie in den Kirchen des Westens. Rituelle Entwicklungen, theologische Konzepte und kulturelle Kontexte, Münster, Aschendorff 2018, p. 441-481.

20 As befits a church in analogia Trinitatis, see: M. Ploeger, Celebrating Church, p. 459-469.
} 
be experienced in the Church today. Such rethinking needed to take place in the Church's common life and interpretation of the faith in particular, ${ }^{21}$ in order to be able to live a life of faith essentially identical to that of the early Church. A merely conservative attitude would, of course, prevent precisely that as it necessarily leads to anachronisms. ${ }^{22}$

With these historical and hermeneutical considerations, not everything is said however. When asking the question what the faith and order of the early Church consisted of then and when delineating the early Church, as has been commonly done, as coinciding with the timespan covered by the seven ecumenical councils ${ }^{23}$ and when taking notice of the hermeneutics implied in the appeal to the early Church, answers to this question by Old Catholic theologians are both confident and relatively modest. With confidence, the episcopal-synodal ordering with its Eucharistic focus is stressed, also as the place where the Catholicity of the Church is found primarily. ${ }^{24}$ In a similar manner the dogmas of the ecumenical councils are affirmed, always noting that these also are subject to interpretation in the pneumatological "communio event" of the church. ${ }^{25}$ The Creed of the Councils of Nicaea (325) and Constantinople (381) is recited in the Eucharist on all Sundays and other feast days. In the same vein the Christian canon is affirmed (i.e., the canon of the Septuagint), of course also underlining that a hermeneutical approach is needed. ${ }^{26}$ Inherent to the first point is also the importance of the apostolic ministry as a means for enabling the unity of the church, both synchronically and diachronically and socially and spiritually. In line with this, also the liturgical life of the early Church, with its eucharistic life as its core, is considered to be part of the faith and order of the early Church. Beyond this, a general appeal is made to the insights and practices of the early Church as a first point of orientation for contemporary ecclesial life,

${ }_{21}$ See for the first position, representatively: Andreas Rinkel, Dogmatische Theologie I-IV, Amersfoort, 1956, I, p. 8; for the second, also representatively: K. Stalder, Die Wirklichkeit Christi; idem, Sprache und Erkenntnis.

22 See: P. B. Smit, Traditie als Missie.

23 I.e., with a focus on their dogmatic content, "the catholic faith as expressed in the Church in the east and west by the seven Ecumenical Councils" in: U. von Arx, M. Weyermann (eds.), Statut, preamble, par. 2, see representatively: M. Ploeger, Celebrating Church; A. Suter, "Altkatholische Kirchen".

24 See: U. von Arx, "Was macht die Kirche".

25 See: Herwig Aldenhoven, "Charakter, Bedeutung und Ziel der Dialogtexte", in: U. von Arx (ed.), Koinonia auf altkirchlicher Basis, Bern, Stämpfli 1989, p. 27-44; A. Suter, "Altkatholische Kirchen", with emphasis on the soteriological content rather than on the letter of dogmas; see also: M. Ploeger, "De relevantie van een doordachte geloofsvisie. Over het vak "systematische theologie» in oud-katholiek perspectief", in: K. van der Kooi et al. (eds.), Vele gaven, één Geest, p. 63-77.

26 See: P. B. Smit, Traditie als Missie. 
but, as noted above, with an appeal to the Spirit. Only in the Spirit and in the communion brought together by the Spirit, i.e. the church, qua "permanent Pentecost," ${ }^{27}$ can the ancient faith be received in such a way that Christ, as a salvific reality ("Christ event"), becomes present to the Church again in a manner essentially identical to the manner in which Christ was present to the earliest ekklesia. Life in communion in the Church today is thus also life in communion with the Church of the past and, in fact, given its basis in the Christ event made present pneumatologically, it is the same communion with God. ${ }^{28}$

The relative modesty when it comes to answering the question what the content of the faith of the early Church is precisely, has much to do with the other aspect of the faith and order of the early Church: its role as a hermeneutical principle. The ecclesiological structure of the early Church, i.e., its episcopal-synodal ordering and its character of a communion of communions with a very limited hierarchy among the local churches (qua Eucharistic assemblies around a bishop that gather at a supra-local level under the presidency of a 'primate'), serves as a means of interpretation in communion. ${ }^{29}$ Such a structure also determines the manner, in which insight into the tradition can be discerned: through a communal process of dialogue and reception only. ${ }^{30}$ Such discernment in communion can, if the question at stake demands this, concern a global communion of communions of churches (that are themselves communions). In this case, a form of papal primacy can be required to preside over such a communion of communions. ${ }^{31}$ To be sure - and in line with the pneumatological emphasis above -, this is more than just a 'democratic' form of governing the Church: it aims at a manner of discerning the truth that does justice to the insights and charismata of all the baptized and all the churches in their respective contexts, ideally based on consensus. This ecclesiological and with that hermeneutical emphasis leads to a certain reticence when it comes to using the early Church for laying down the law too quickly concerning the form and content of the faith of the early Church in detail. Theological and historical insight into what

27 See: H. Aldenhoven, "Charakter, Bedeutung und Ziel”, with reference to the work of John Zizioulas.

28 See the argument by M. Ploeger, Celebrating Church.

29 See: Visser, Het ideaal van de ecclesia; idem, "Kirche"; idem, "Vincentius".

30 See: H. Aldenhoven, "Charakter, Bedeutung und Ziel"; U. von Arx, "Was macht die Kirche"; P. B. Smit, Traditie als Missie; M. Ploeger, Celebrating Church.

31 See, e.g., the considerations in the documentation of the international Roman Catholic - Old Catholic dialogue: Kirche und Kirchengemeinschaft Erster und Zweiter Bericht der Internationalen Römisch-Katholisch - Altkatholischen Dialogkommission 2009 und 2016, Paderborn, Bonifatius 2017. 
tradition is and how it functions (as an evolving organism), attention to the necessity of the ongoing 'translation' of the faith in new contexts, and the possibility inherent to that process that new or forgotten aspects of the faith are discovered or rediscovered, as well as a certain eschatologischer Vorbehalt ('eschatological reservation') when it comes to definite formulations of what the faith amounts to, require this. ${ }^{32}$

In order to further unpack all of this, an example is appropriate at this point: In order to understand how this appeal to the faith and order of the early Church works in practice and to simultaneously address a topic that concerned Old Catholic theologians from the late 1960s until the turn of the millennium, here the case of the Old Catholic Churches' progression towards the ordination of women to the apostolic ministry will be considered in more detail.

\section{The Ordination of Women and the Appeal to the Early Church: A Test Case}

One of the most prominent discussions in Old Catholic theology in the latter part of the $20^{\text {th }}$ century concerned, at least on the surface, the ordination of women to the apostolic ministry. Under the surface, however, other questions were at stake as well. These included the theology of the ordained ministry as such, the role in theology of issues raised in society (such as women's rights), the manner of continuing the faith of the early Church (the question of tradition), questions of theological anthropology, the theological significance of gender, the relationship of the churches of the Union of Utrecht among each other and the ecumenical dimensions of this question. ${ }^{33}$ Here, the discussion and its eventual outcome will be presented from the point of view of what this meant for the Old Catholic understanding of the appeal to the early Church in the context of ecumenical dialogue and accountability. In doing so, the broader questions just mentioned will serve as an initial starting point.

From the late 1960s onwards, prompted by ecumenical relationships, such as with the (post-Vatican II) Roman Catholic Church (cf. e.g., Dei Verbum on tradition, Lumen Gentium on the church), the preparations of

\footnotetext{
32 See: P. B. Smit, Traditie als Missie, and the literature referred to there.

33 See in general: idem, Ecclesiologies, p. 389-419, for surveys of the developments and debates: U. von Arx, "Die Debatte über die Frauenordination in den Altkatholischen Kirchen der Utrechter Union”, in: Wolfgang Bock, Wolfgang Lienemann (eds.), Frauenordination, Heidelberg, Forschungsstätte d. Ev. Studiengemeinsch 2000, p. 157-20; Angela Berlis, "Women's Ordination in the Old Catholic Churches of the Union of Utrecht", in: Ian Jones et al. (eds.), Women and Ordination in the Christian Churches: International Perspectives, London, T\&T Clark 2008, p. 144-154.
} 
the dialogue with the Orthodox Churches (and the appertaining reception of koinonia theology), involvement in the broader ecumenical movement (in particular: Faith and Order, cf. on tradition the outcome of the 1963 Faith and Order Conference of Montreal), and the broader social developments often associated with the year 1968, Old Catholic churches and their theologians saw themselves in a position in which they needed to engage in renewed study and reflection of a number of interrelated questions. These were in particular: the significance and appeal to the early Church (and in that context: the interrelationship between Scripture and tradition) and the theology of the ordained ministry as such and the admission of women to the apostolic ministry. The latter two questions proved to be catalysts for addressing the former, as repristination of a theology of the ordained ministry was called for in a new theological and social setting.

The ensuing discussion led to a consensus at the end of the 1970 s and the early 1980s that an unqualified and therefore uncritical appeal to the undivided Church of the first millennium was no longer sufficient. ${ }^{34}$ Instead, a different view was needed, expressed representatively by the 1981 International Old Catholic Theologians' Conference:

Die Kirche muss... ein fortwährender Prozess der Wahrheits- und Entscheidungsfindung und des gemeinsamen Handelns sein, an dem alle beteiligt sind. Diese Beteiligung aller zu ermöglichen ist die Aufgabe des Amtes in Apostolischer Sukzession. Die Altkatholischen Kirchen der Utrechter Union glauben, dass sie damit die Tradition (Leben und Aufgabe) der ungeteilten Kirche des 1. Jahrtausends in einer den heutigen Problemen angemessenen Weise weiterführen. ${ }^{35}$

The appeal to the early Church is therefore an appeal both in terms of form and content, as would be further developed in the course of the following years, as is apparent in a statement by the 1995 International Old Catholic Theologians' Conference, the conclusion of which was already cited above. ${ }^{36}$ In line with the general development of Old Catholic theology, this conference aimed at recovering a particular aspect of the recourse to the early Church, namely the synodal and conciliar style of processes of discernment, in order to do justice to an appeal to the faith and order of the early Church.

Accordingly, the discussion about the ordained ministry in general, which constituted the broader context of the entire discussion and the

\footnotetext{
34 See: International Old Catholic Theologians' Conference, "Erklärung der Internationalen Altkatholischen Theologentagung 1981", in: Internationale Kirchliche Zeitschrift 73 (1983), p. 65-69, esp. p. 68, n8.

35 International Old Catholic Theologians' Conference, "Erklärung”, p. 67-68.

36 See: International Old Catholic Theologians' Conference, "[Resolution]”.
} 
ordination of women in particular took the shape of a conversation in communion, ${ }^{37}$ both within the member churches of the Union of Utrecht, among them through 'instruments of communion' such as the IBC, the International Old Catholic Theologians' Conference, and International Old Catholics' Congresses, and with ecumenical partners, such as churches in communion (notably the churches of the Anglican Communion), the Orthodox Churches and the Roman Catholic Church. ${ }^{38}$ The Roman Catholic position left, at this point, relatively little room for discussion, given the publication of Ordinatio sacerdotalis in 1994 (preceded by Inter insigniores in 1976). ${ }^{39}$ No further discussion was pursued, therefore. With Anglican partners, the theology of the ordained ministry was discussed in general, as it was with Orthodox partners, leading to joint statements on a shared and renewed view of the ordained ministry, but not yet to a definitive position on the ordination of women to it. ${ }^{40}$ However, as Anglicans were generally moving into the direction of the ordination of women and, at least, the relationship of communion was not threatened by its introduction on either side of the relationship, for instance when the Episcopal Church in the USA in 1976 officially ordained women to the priesthood, the conversation with the Orthodox Churches, not generally known for their supportive stance regarding the ordination of women to the apostolic ministry, was pursued in particular as a way of testing the viability of the ordination of women to the apostolic ministry as an ecumenically recognizable faithful reception of the faith and order of the early Church.

Accordingly, a consultation took place in 1996, consisting of two meetings of a commission of experts and meeting with the blessing of the Ecumenical Patriarch and the Archbishop of Utrecht. The results of this consultation, which, despite their publication in English and German, ${ }^{41}$ have remained somewhat hidden, came at the time as a surprise to all involved (and all observing): the joint consultation reached the unanimous conclusion that there were no theological objections against the ordination of

37 See for this and the following: P. B. Smit, Ecclesiologies, p. 391-419.

38 As discussed in: U. von Arx, "Die Debatte"; A. Berlis, "Women’s Ordination".

39 Though it should be noted that the ordination of women to the apostolic ministry was no hindrance for the initiation, by the Vatican authorities, see: Kirche und Kirchengemeinschaft.

40 See for an overview of Old Catholic ecumenism in this period P. B. Smit, Ecclesiologies, p. 359-391.

41 I.e.: U. von Arx and Anastasios Kallis (eds.), Bild Christi und Geschlecht. "Gemeinsame Überlegungen" und Referate der Orthodox-Altkatholischen Konsultation zur Stellung der Frau in der Kirche und zur Frauenordination als ökumenischem Problem. Levadia (Griechenland) und Konstancin (Polen) 1996, in: Internationale Kirchliche Zeitschrift 88 (1998), p. 65-348; English translation (Duncan Reid) in: Anglican Theological Review 84 (2002), p. 489-755. The German edition contains the full supporting patristic source materials. 
women to the apostolic ministry. Both the results of the consultation as well as its line of argument as they appear in the "Common Considerations" 42 of the consultation are of interest here, as they show how an appeal to the early Church factually functions and how a faithful reception of the faith and order of the early Church has its place in an ongoing search for ecclesial communion. This approach comes close to what would later be outlined in the Anglican - Orthodox Cyprus Agreed Statement). ${ }^{43}$

The "Common Considerations" are prefaced by "preliminary remarks" by the editors, Old Catholic theologian Urs von Arx and Orthodox theologian Anastasios Kallis. They outline how the participants in the consultation agreed that in the earliest history of the Church

At first, tendencies not to treat men and women differently based on gender, as both are viewed as parts of Christ's body, allowed for multiple ecclesial ministries, even for what we would nowadays call leadership positions. ${ }^{44}$

This changed, the more the church was influenced by gender norms current in (Greco-Roman imperial) society, leading to the exclusion of women from such (priestly) roles. As this happened early on, the effect was that

This state of affairs, initially caused by socio-cultural conditions, has become surrounded with the aura of holy tradition in the course of the Church's pilgrimage to its destination in the doxa of God." (ibidem)

Yet, another, newer social development has given reason to begin reassessing this:

This was to be confronted with the (admittedly socio-culturally conditioned) movement that evolved in modern Europe and North America advocating equality for women, and with the realization that various traditional cultures are characterized by the phenomena of patriarchalism and androcentrism. This raised the question as to whether there are inevitable and dogmatic reasons for excluding women from being priests. ${ }^{45}$

\footnotetext{
${ }^{42}$ U. von Arx, A. Kallis, "Common Considerations of the Orthodox-Old Catholic Consultation on the Role of Women in the Church and on the Ordination of Women as an Ecumenical Issue”, in: Anglican Theological Review 84 (2002), p. 503-506. German original: "Gemeinsame Überlegungen' der Orthodox-Altkatholischen Konsultation zur Stellung der Frau in der Kirche und zur Frauenordination als ökumenischem Problem”, in: idem (eds.) Bild Christi.

43 Anglican - Orthodox Dialogue, The Church of the Triune God: The Cyprus Agreed Statement of the International Commission for Anglican - Orthodox Theological Dialogue, London, Anglican Communion Office 2006.

44 U. von Arx, A. Kallis, "Common Considerations", p. 501-502.

45 Ibidem, p. 502.
} 
The reason for reconsidering the witness of the early Church is, therefore, social and contextual. As it will become clear from what follows, the argument itself is not determined by arguments derived from, for instance, a discourse on social justice, but rather from one concerned with early Christian soteriology and the theological anthropology inherent to it. Prior to making this argument, first a matter of method is clarified:

The answer to this question cannot simply be taken out of the history of the Church, as long as that history is identified as the "holy tradition." In other words, it does not make sense to take statements of Church fathers, made in specific historical and cultural contexts, and apply them to the questions that have emerged from the spiritual needs of people today in our own cultural context. Rather, a hermeneutical consciousness is required. ${ }^{46}$

Next, a number of reasons are mentioned as to why it is not possible to ordain women to the apostolic ministry:

Among the objections to the ordination of Christian women raised by churches in the East and the West alike, there are some that claim to be independent of time or specific sociological context. The male gender of priests is derived, according to these arguments supposedly not conditioned by culture, from an indispensable connection between the function of the priest to represent Christ (or his "Christ-iconicity") and his male sex and gender. These reasons are ultimately untenable. The same applies to the arguments with Christ-Adam and Eve-Mary typologies when they are used to explain a gender-specific difference that would make the ordination of women impossible. ${ }^{47}$

The traditional character of these argument is acknowledged, yet also relativized with reference to another strand of tradition:

Although the patterns of both arguments reflect formal-patristic thought, they do not correspond to the tradition, since they ignore the universal salvific significance, inclusive of both men and women, of the incarnation of God's Logos. ${ }^{48}$

Thus, as will happen in the "Common Considerations" themselves as well, particular aspects of tradition that can be seen as socio-cultural in nature primarily are relative here with reference to the theological core of the tradition of the early Church, i.e. soteriology and its implied anthropology.

Von Arx and Kallis then acknowledge the complexities of the discussion surrounding gender difference and equality noting that

\footnotetext{
46 Ibidem, p. 502.

47 Ibidem, p. 502-503.

48 Ibidem, p. 505.
} 
The tradition of the early Church, whose founders articulated their faith in different socio-cultural environments from ours, can provide us with neither general basic guidelines nor explicit guidance for each and every case. However, they provide something of a foundation ... when they speak of the incarnation of God's Logos - in which Jesus Christ took the common nature of men and women - and of the restoration of the image of God (cf. Gen. 1.27) that men and women alike find in him. ${ }^{49}$

Subsequently, the factor "culture" is again stressed as one that largely determines the possibility of the admission of women to the apostolic ministry or not ("certain cultural factors"). ${ }^{50}$ They also note, already referring proleptically to the findings of the consultation as a whole, that no "compelling dogmatic or theological reasons" were found "for not ordaining women to the priesthood." ${ }^{51}$ As this is the case:

This means that the ordination of women could not fundamentally call into question or destroy the communion and unity of the church or the moves toward restoring broken communion and unity. ${ }^{52}$

In the subsequent "Common Considerations" some of these arguments return, yet it is worthwhile to outline them in sequence, so as to do justice to the statement's coherence. Having positioned the conversations in the context of an ongoing dialogue and discernment of the Gospel (and with that of the unity of the Church), building on the insights of the official Orthodox - Old Catholic dialogue (1975-1987) first a common view of tradition is outlined:

In faithfulness to the treasure of tradition, we discern tradition as a process, directed by the Spirit of God, of the dynamic contextualization of the faith for the life and the witness of the Church in its ever-changing contemporary situation. This provokes questions concerning the appropriate way of dealing with the tradition (the hermeneutical problem)..$^{53}$

Next, an ecclesiological observation is made. The consultation observes "that today churches justly emphasize the dignity of the laity and especially of women, and that they appreciate the fact that these people occupy an appropriate place in the mission of the church". ${ }^{4}$

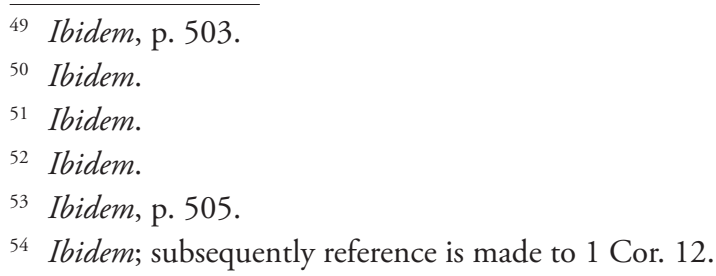


Subsequently, the consultation reports that it has researched the tradition of the early Church based on the above-mentioned understanding of tradition; in particular attention was given to

the historical data which was brought forward as a rationale for the "male character" of the priesthood: the maleness of the incarnate Son of God, Jesus Christ's choosing of men in the circle of the twelve, the exclusive appointment of men to the priestly office of the Church, as well as the corresponding argumentation with regard to typologies (e.g., Adam-Christ, Eve-Mary) and with ideas of the priest being the image or representation of Christ. ${ }^{55}$

On the basis of a consideration of these various traditions and arguments based on them, the following is concluded:

We have reached the common conclusion that there are no compelling dogmatic-theological reasons for not ordaining women to the priesthood. The soteriological dimension of the Church is decisive for us: the salvation of humankind and the entire creation in Jesus Christ in whom the new Creation is being accomplished. We were especially guided by the conviction that was central to the ancient Church: only that which has been assumed and united with God has been saved. It is human nature, common to men and women, that has been assumed by our Lord. ${ }^{56}$

Following on this, allowance is made for the role of socio-cultural ("nontheological") factors in the factual decision-making of churches, but these do not infringe upon the validity of this theological view.

With this, both the basis upon which Old Catholic Churches proceeded with the ordination of women from 1998 (Germany 1996) onwards, and the manner in which the appeal to the early Church functions in Old Catholicism have been laid out. The characteristics of the latter include a discernment in communion, through the episcopal-synodal structures of each of the local churches that are part of the Union of Utrecht, among these churches in conciliar communion, and among communions of communions in discussions with churches in communion and with churches with which communion is sought. This method of discerning in communion responds to questions raised by the contemporary context of the churches and makes use of the tools of academic theological scholarship. In this way the churches are able to critically reassess, as part of the process of traditioning that shapes the life of these churches, whether their position on a topic like the ordination of women is still the most appropriate reflections of the faith and order of the

\footnotetext{
55 Ibidem.

56 Ibidem.
} 
early Church and enable a faithful witness to Christ, who is at the heart of the living tradition of the church (cf. the formulations of the Fourth World Conference on Faith and Order, Montreal 1963).

\section{Concluding Observations}

A number of things can be maintained with regard to the Old Catholic appeal to the early Church in the context of ecumenical dialogue.

First, it could be outlined how in Old Catholic theology the appeal to the early Church is at least as much an appeal to the 'contents' of the early Church as to the 'form' of the early Church, in terms of its being structured as a community geared towards discerning the truth in communion. The faith of the early Church needs to be discerned in the manner of the early Church. This discernment in communion also amounts to discernment in communion with ecumenical partners. In other words, the appeal to the early Church qua basis for Old Catholic theologizing connects organically with the Old Catholic hope that rediscovering the faith of the early Church can provide a basis for ecclesial rapprochement and reunion, given that such rediscovery implies and demands discernment in dialogue and communion with other churches seeking to do the same.

Second, the manner in which such discernment takes place concretely, illustrated here with reference to the Old Catholic discussion about the ordination of women to the apostolic ministry in general and to the consultation with Orthodox theologians in particular, shows that the contours of this appeal are hermeneutical and theological in character. Rather than a 'copy-and-paste' approach to the faith and order of the early Church, it is endeavored to ask not just 'how' things were in the past, but also why they were as they were; this aims at uncovering the theological rationale embedded in various beliefs and practices, which may then be reappropriated in a new context, while avoiding the pitfall of permitting this context to determine the outcome of such a process, even if it is important for enabling, even necessitating the consideration of new questions and new answers on the basis of the tradition of the early Church. 